\title{
An Analysis of the Literature on Instruction in Academic Libraries
}

This research examined the literature on instruction in academic libraries to determine the journals in which such articles were published, the types of articles, and changes in the types by year. Results show that Research Strategies, Reference Services Review, College \& Research Libraries, The Journal of Academic Librarianship, and Reference \& User Services Quarterly have published the most articles on academic library instruction. The most frequent types of articles were those classed as essays, which included articles on current developments and the philosophy of instruction, and articles discussing instruction for searching online catalogs and databases. No significant differences were determined for changes in type of articles by the year in which they were published. For articles that were research-based, surveys or questionnaires were the most frequently used data collection tool. The most frequently used inferential statistical tests were chisquares and t-tests.

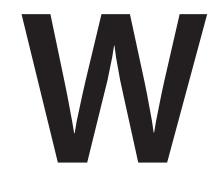

hat is the structure of the literature on instruction in academic libraries? Where are the articles published? How many are based on empirical research? These are the basic questions that have driven this research.

In 1980, the Research Committee of the Association of College and Research Libraries (ACRL) Bibliographic Instruction Section published the "Research Agenda for Bibliographic Instruction." In 2000, the ACRL Instruction Section charged its Research and Scholarship Committee to update this document, and the revised agenda was published in the February 2003 issue of College $E$ Research Libraries News. ${ }^{2}$ Both of these documents sought to formulate questions that could facilitate research of library-related instruction in academic libraries. The 1980 research agenda organized its research questions into three general topics: library skills, defining needs and measuring actual levels; the design and implementation of library and bibliographic instruction programs; and management aspects of bibliographic instruction. Similarly, the 2003 research agenda focused on four areas: learners, teaching, organizational context, and assessment. Both research agendas sought to increase the level of research being done on instruction within academic libraries.

Although the current study was not directly based on the updated research agenda, it does provide an exploratory analysis of the literature of instruction that can be used as a springboard for additional research into the topic of instruction and information literacy in the academic library. This research asked several questions:

1. In which journals are articles on instruction in academic libraries published?

2. What are the topics of the articles that have been published?

\section{Gregory A. Crawford and Jessica Feldt}

Gregory A. Crawford is Head of Public Services at the Penn State Harrisburg Library in Middletown. Jessica Feldt is Webmaster, Pennsylvania Federation of Museums and Historical Organizations, Harrisburg. Submitted for review October 22, 2004; revised and accepted for publication September 27, 2005.

Reference \& User Services Quarterly, vol. 46 , no. 3 , pp. $77-88$ (c) 2007 American Library Association. All rights reserved.

Permission granted to reproduce for nonprofit, educational use. 
3. How has the literature of instruction in academic libraries changed over the years?

4. What is the nature of research articles on instruction in academic libraries?

5. For research articles, what are the research methods used and what types of statistics are utilized?

\section{LITERATURE REVIEW}

The literature on bibliographic instruction is abundant, but research that actually examines the nature of articles in the field is sparse. Two articles by Rader stand out as important reviews of instruction and information literacy. In her 2000 article in Reference Services Review, Rader reports on the almost 3,900 articles she has reviewed over the previous twenty-five years in her annual summary of the literature of instruction. ${ }^{3}$ Similarly, in her 2002 article in Library Trends, she provides a brief summary and analysis of more than five thousand articles for the thirty years included in her review. ${ }^{4}$ In both articles, Rader provides a very succinct and useful summary of the overall publication trends in the field of instruction and lists what she classes as the best publications from the time periods in her review. She does not, however, provide an article-level analysis of the literature that addresses the journals or the types of articles represented, nor does she attempt any statistical analyses of the trends over time. She does draw very brief, although useful, conclusions on specific topics such as information literacy and higher education, user instruction in schools, and assessment of information literacy.

The most important article relevant to the current study is by Edwards, who performed an analysis of the journal literature on bibliographic instruction for the years 1977 to $1991 .{ }^{5}$ She examined 595 articles from twenty-one library and information science (LIS) journals and classified them as either research or non-research articles. She also classified them by principal research method employed, subject studied, and library type. She found that 178 (29.9 percent) of the articles in her study were research based, with Research Strategies providing the greatest percentage of the research articles ( 31.5 percent). The most used research methods were surveys (41.0 percent), evaluation (28.1 percent), and experimental design (12.4 percent). More than two-thirds of the articles discussed instruction in academic libraries-the effectiveness of instruction was the leading topic of research articles and computerassisted instruction was the most frequent topic of non-research articles.
Koufogiannakis, Slater, and Crumley conducted a content analysis of librarianship research from ninety-one journals. ${ }^{6}$ They examined 2,664 journal articles and classified 807 (30.3 percent) as research. Although they examined the various domains of the library research, instruction was not included as a category. Of the research articles they classified, the greatest number used questionnaires or surveys to gather information. The journals publishing the most research-based articles were JASIST, Scientometrics, Information Processing and Management, College \& Research Libraries, Journal of Library Administration, and Bulletin of the Medical Library Association. They also found that the highest proportion of research articles could be classified as descriptive studies, and the most frequent research tool was the survey or questionnaire. In another study, which examined only the LIS literature of 1984, Feehan et al. found, after eliminating weekly publications and state and regional journals, that 27.7 percent of the articles published that year could be classified as research. ${ }^{\top}$

In another article that analyzed the library literature, Buttlar examined 1,725 articles drawn from sixteen journals for the characteristics of the authors and the content of the individual articles. ${ }^{8}$ She found that more than 60 percent of the articles in her study could be classified as non-research. The most frequent types of research were surveys and historical studies. The top journals that published research-based articles were Journal of the American Society for Information Science, College \& Research Libraries, Journal of Academic Librarianship, Library \& Information Science Research, and Libraries and Culture. The author did not analyze the types of statistics employed in the articles studied. Similarly, Watson-Boone, in a small study of articles appearing in Journal of Academic Librarianship, found that the articles used only six research methods, with surveys accounting for half the articles. ${ }^{9}$

Kim and Kim studied the articles appearing only in College \& Research Libraries from 1957 to $1976 .{ }^{10}$ They found that over time there was an increase in the number of articles that were based on quantitative measures, with the majority of these articles using survey method. Most used simple descriptive statistics such as percentages and frequencies, with less than a quarter using inferential statistics such as chi-square, correlation, or t-tests. Similarly, statistical methods used in LIS research was the focus of an article by Wallace. ${ }^{11}$ He found that almost three-fourths of the articles included no statistics, while 20 percent provided descriptive statistics and only 6 percent used inferential statistics. 
In his article entitled "College Libraries and the Teaching/Learning Process: A 25-Year Reflection," Farber gives an excellent overview of the social and education forces that have driven the development of quality academic library instruction programs. ${ }^{12}$ As he notes in his essay, "there is no question that the convergence of the user instruction movement and the impact of the new technologies has given today's college library a much more significant role in the teaching/learning process." ${ }^{13}$ Yet his purpose was not to provide a detailed analysis of the literature but to present his personal observations of changes over his long and influential career. Similarly, Lorenzen provides an excellent overview of the history of library instruction in the United States. ${ }^{14}$ Although he does not give an analysis of the literature, he does summarize many of the major articles that helped shape the field of academic library instruction.

As would be expected, the majority of articles on instruction have focused specifically on topics such as using technologies in instruction, teaching different levels of library users, or employing various classroom techniques for instruction. Many articles have dealt with new technologies and how they have been incorporated into traditional bibliographic instruction. For example, Shill reviewed the library literature on how technology has impacted instruction with academic libraries. ${ }^{15}$ Likewise, Bober, Poulin, and Vileno performed a critical review of the literature from 1980 until 1993 on evaluating library instruction in academic libraries. ${ }^{16}$

Other articles have examined the literature on different methods of instruction. For example, Sheridan reviewed the literature of the Writing Across the Curriculum movement and its importance to academic librarians. ${ }^{17}$ Similarly, Trefts and Blakeslee used their literature review as a springboard for their discussion about livening-up bibliographic instruction with comedy. ${ }^{18}$ A substantial part of their review was in literature outside library journals, but they did discuss the few articles they could find in library journals. Trefts and Blakeslee emphasized that most of the articles they found tended to have different objectives from their own, but could be used as a jumping off point for discussing the topic of using comedy in library instruction.

Another set of articles discusses specific user populations, such as undergraduates or students in two-year technical education programs, generation Y, distance education students, or student athletes. ${ }^{19}$ As would be expected, most of these articles contained an abbreviated review of the bibliographic instruction and information literacy literature, but only as it pertained to the particular topic or debate, not on the literature of instruction as a whole.

A major type of topical examination of the instruction literature was exemplified by articles which were largely annotated bibliographies. For example, Rader has regularly published a bibliography of the literature on instruction in Reference Services Review. For the 2002 article, Johnson joined Rader in compiling the bibliography for 2001, and they identified 281 articles, a growth of forty-four from the previous year. ${ }^{20}$ As another example of the annotated bibliography article, Rutledge Elsbernd and her coauthors compiled a listing of articles on OPAC instruction that could act as a guide for librarians working to transition from card catalogs to OPAC. ${ }^{21}$

\section{METHOD}

For this current research, the ERIC database was used to derive a set of articles for analysis. ERIC was chosen due to its coverage of the LIS literature, the date range covered, and the availability of abstracts and descriptors for most articles. The authors fully realized that the selection of the ERIC database precluded finding many articles on academic library instruction since the number of library-related journals covered by ERIC is somewhat limited. Almost all the major journals in the field, however, are indexed by ERIC, and other education-related journals that may discuss academic library instruction are also included. The availability of an excellent controlled vocabulary and the presence of abstracts provided greater ease in identifying relevant articles for use in the study. The search strategy utilized the following descriptors and structure:

(de=college libraries or academic libraries) and de=library instruction.

The descriptor "library instruction" alone was used in the search. Other related topics, such as information literacy, and narrower topics, such as course-integrated library instruction, were not included since those descriptors came into use many years after the ERIC database began. The library instruction descriptor has been used since the beginning of the database, thus providing the most consistent terminology for selecting articles for this study. Inclusion of other terms, of course, would have increased the number of articles available for analysis, but the content of the articles may have also changed significantly. The search itself was limited to journal articles only so that ERIC 
documents were eliminated from the final results. A total of 791 articles were identified for inclusion in the study for the time period 1971-2002. The year 2002 was chosen as the endpoint to ensure that complete indexing would be available at the time of the database search for journals to be included in the study.

The next step of the analysis involved the creation of a matrix that identified the major variables that were to be studied. The resulting matrix contained categories for publication year, journal in which the article appeared, type of article, research nature of the article (yes or no), type of research, number of cases in study, and types of statistics used. After a cursory examination of the results of the search to determine types of articles represented, a preliminary coding plan for article type was created, similar to that provided by Edwards. ${ }^{22}$ The preliminary coding plan included

- general essays (i.e., articles that presented opinions on the state of instruction or discussing current trends);

- instruction in general (i.e., articles discussing the instruction process itself);

- instructional methodology (i.e., articles that focused on the how-to part of instruction);

- programmatic or management issues (i.e., articles on specific aspects of running an instruction program);

- research methods (i.e., how to do research on instruction); and

- literature reviews and bibliographies of instruction literature.

The coding schemes for the type of research represented and the type of statistics employed were developed as the articles themselves were examined.

Using the preliminary coding plan of types of articles, the researchers took a sample of ten articles, and each separately performed a preliminary coding that was reviewed by the other researcher. The level of agreement was high, and after discussion, the basic coding plan was slightly modified for use with the entire data set. Then, the coding under the heading of instruction was recursively expanded into subtopics as found in the literature being reviewed to provide greater depth of analysis. The major subtopics were: course- or assignment-related instruction, computer-assisted instruction, instruction for special populations (e.g., undergraduate or international students), and library-specific instruction (e.g., how to use a specific OPAC or the use of a workbook in a specific library). See the appendix for the final detailed article coding scheme.

Next, each researcher independently coded all the articles for the type of article. After the initial examination of all 791 articles, the researchers had agreed on the coding for more than 87 percent of the total. Then, each article for which there was disagreement was examined by both authors again, and a mutually agreed upon coding was determined. Most disagreements centered on whether the instructional method or the population was the main focus of the article. For example, an article may have been about using a workbook for international students. The researchers needed to determine the major focus of the article in order to assign the proper code (i.e., 2.3b for international students or 2.4e for workbooks). Such coding is not an exact science, and other researchers would inevitably come up with slightly different results depending upon their interpretation of the articles. In several cases, the coding plan itself was recursively modified as a result of the discussion to represent more fully the types of articles in the data set. In general, these changes created more specific coding types for the articles. For example, after finding several articles on how to do instruction with academically deficient students, a code was created for that topic. Any changes in the coding plan also resulted in examining previously coded articles to determine if any needed to be recoded.

Each article was also examined to determine if it could be classified as research based. For those articles classified as research, the type of research, the number of cases included, the return rate for surveys, the use of descriptive statistics (coded as yes or no), the use of inferential statistics (coded as yes or no), and the type of inferential statistics used were coded. The types of research included such methods as surveys and questionnaires, experimental or quasi-experimental design, case studies, and focus groups or interviews.

All coding information for each article was entered into the variable matrix using Microsoft Excel. Once all the coding had been completed in Excel, the Statistical Package for the Social Sciences (SPSS) software was used to run preliminary tests on the data to determine potential coding errors-e.g., incorrect dates or incorrect article type codes. After any discovered errors had been corrected, the final analyses were performed using SPSS. Analyses on categorical data were conducted first to determine the number of articles by journal, year, article type, and research-related variables. Then, the data were compressed into year 
ranges and by generic article types so that more sophisticated analyses, such as chi-square tests, could be performed to determine if the types of articles published had changed over time.

\section{RESULTS}

Analyses of the 791 articles show that ninety different journals are represented. Of these, fortythree have published only one article on academic library instruction, thirteen have published two articles, and another eleven have published three. The remaining twenty-three journals published four or more articles related to academic library instruction. Table 1 provides a listing of the journals that are represented by ten or more articles. Appropriately, Research Strategies, a journal devoted to library instruction, contains the most articles on academic library instruction, with a total of 150 matching the search criteria. Following as a distant second is Reference Services Review with eighty-three; next comes the Journal of Academic Librarianship with sixty-seven and College $E$ Research Libraries with sixty-four. Rounding out the top six are Reference \& User Services Quarterly (including RQ) and the Reference Librarian. These six journals alone (6.1 percent of the total number of journals) represent almost 60 percent of the articles included in the study. When all the journals publishing ten or more articles on instruction are considered together, these thirteen journals account for 73 percent of the total number of articles in the study.

Table 2 provides a breakdown by year for all articles. The earliest record was an anomaly dated from 1971, with the next records occurring in 1978. The average number of articles per year was 30.42 with the maximum being fifty-six in 1995. Only three years saw the publication of fifty or more articles (1992, 1995, and 2002). Eleven years had forty or more articles published. The sixyear span from 1990 to 1995 included the greatest concentration of articles on instruction and represents almost 36 percent of the total articles, showing a growing interest in the topic of instruction over that time period.

Table 3 presents the types of articles published. The two largest categories of articles are general essays (15.2 percent) and instruction for searching online catalogs and databases (11.6 percent). Together these two categories represent more than 25 percent of the total number of articles. Articles on course- or assignment-related instruction (9.9 percent), programmatic and management issues (9.0 percent), and specific institution instruction (8.2 percent) round out the top five types of articles. In total, the top five categories cover more than 54 percent of the articles while eleven separate categories are represented by twenty or fewer articles. Surprisingly, articles specifically focused on teaching the use of the Internet accounted for only twenty-five articles (3.2 percent), but this may be misleading because articles on specific databases, some of which were Internet-based, were coded under the heading for instruction on searching online catalogs and databases.

A more detailed analysis examined the journals and the types of articles that they published. For this analysis, articles on instruction of special populations (categories 2.3a through 2.3h) and articles on library-specific instruction (categories 2.4 a through $2.4 \mathrm{f}$ ) were compressed into two broader, more inclusive categories. Table 4 provides a breakdown of the types of article and the journals that published the most articles within those specific topics. For articles coded as general essays, the Journal of Academic Librarianship published the greatest number of articles, followed by

Table 1. Journals with Ten or More Articles on Library Instruction

\begin{tabular}{lcc}
\hline Journal & Number of Articles & Percent of Total Articles \\
Research Strategies & 150 & 19.0 \\
Reference Services Review & 83 & 10.5 \\
Journal of Academic Librarianship & 67 & 8.5 \\
College E Research Libraries & 64 & 8.1 \\
RUSQ (and RQ) & 50 & 6.3 \\
Reference Librarian & 43 & 5.4 \\
Library Trends & 32 & 4.0 \\
Community and Junior College Libraries & 23 & 2.9 \\
Library Journal & 15 & 1.9 \\
Catholic Library World & 14 & 1.8 \\
Journal of Library Administration & 14 & 1.8 \\
Computers in Libraries & 13 & 1.6 \\
Information Technology and Libraries & 10 & 1.3 \\
Total & 578 & 73.1 \\
\hline
\end{tabular}


Table 2. Total Number of Articles by Year for All Articles

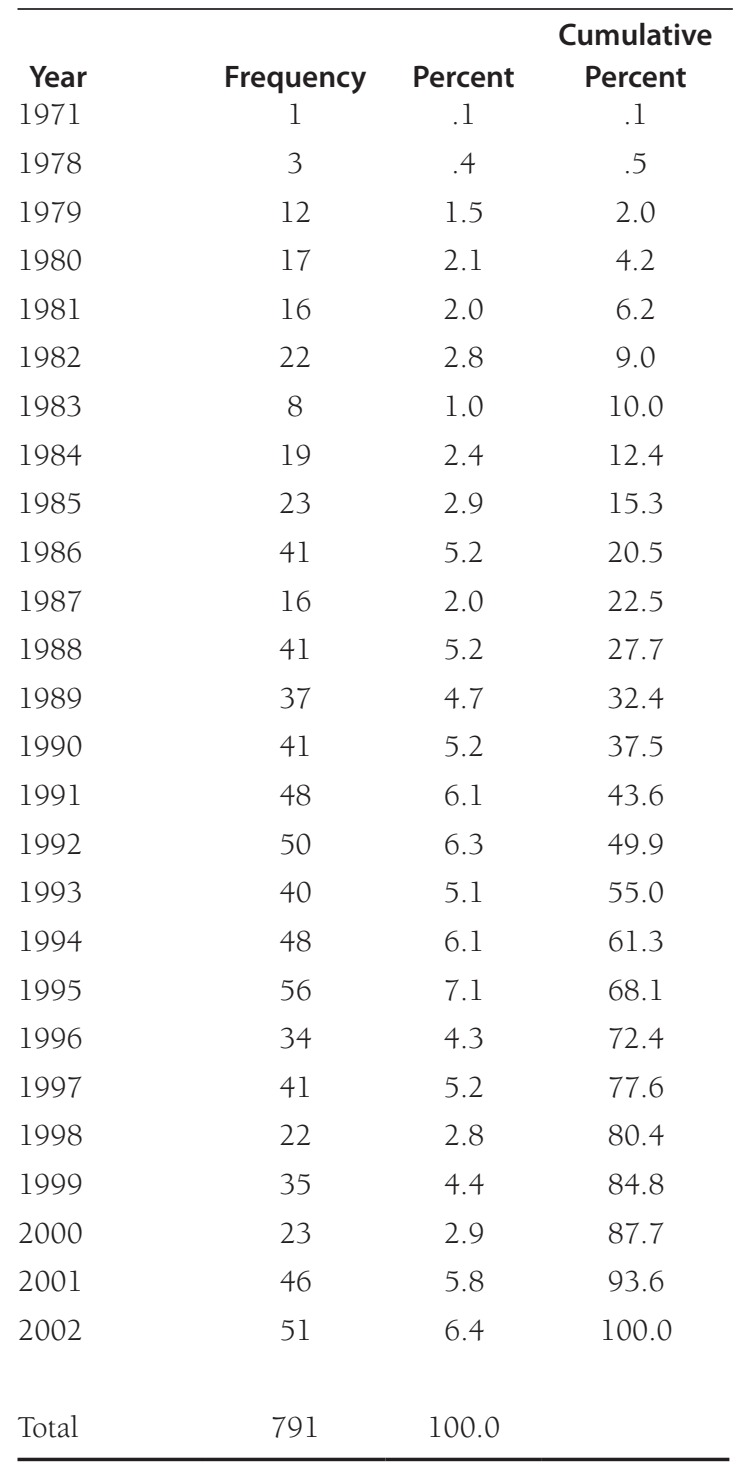

Research Strategies, College \& Research Libraries, and the Reference Librarian. Together these four journals accounted for slightly less than half (44.2 percent) of all articles in the category. Research Strategies and Reference Services Review accounted for more than half (53.8 percent) of the articles on course- or assignment-related instruction. Similarly, for articles on specific populations, Research Strategies, the Journal of Academic Librarianship, and Reference \& User Services Quarterly published 43 percent of the articles. Five journals (Research Strategies, College \& Research Libraries, Reference \& User Services Quarterly, Reference Services Review, and the Journal of Academic Librarianship) were responsible for more than half (50.4 percent) of the articles in the category of library-specific instruction. Research Strategies was responsible for the most articles on instruction preparation/teaching methodology, followed by College $\&$ Research Libraries and Reference Services Review. Together, these three journals provided more than half (51.6 percent) of the articles for that topic. Finally, thirty-three journals published articles on programmatic and management issues, with only three (Reference Services Review, Research Strategies, and the Reference Librarian) publishing more than a third of the articles (34.7 percent).

Next, the types of article by the year published were examined. For most article types, the number of articles was fairly evenly spread throughout the years included in the study. There were some notable exceptions, however. Only three years1993, 1995, and 1999-account for forty-one of the 120 articles (34.2 percent) coded as general essays. For these years, the average of 13.67 general-essay articles per year is much greater than the overall average of 4.6. As would be expected, the number of articles on Internet instruction, while small, began in 1993 with the peak coming in 1996 when eight articles were published. Also, only three articles on audio-visual, multimedia, and microforms have been published after 1989 , which may indicate the reduction in the need for such materials in libraries as the Internet has grown. Similarly, only one article dedicated to the use of workbooks has been published since 1994, indicating a possible change in the focus of academic library instruction. Although articles on programmatic and management issues have been published steadily, the number peaked in 2002 at seventeen, with the next highest amount coming in the previous year (2001, ten articles).

As shown in table 5, an additional analysis using specific time ranges and condensed article categories was undertaken to determine broader changes. For ease of analysis and explication, the years were grouped into six categories (i.e., $1=1970$ s $2=1980-1984 ; 3=1985-1989 ; 4=1990$ 1994; 5=1995-1999; and 6=2000s). Next, the article types were condensed into six major categories by collapsing all those articles categorized as specific types of instruction (i.e., the categories labeled as general instruction, instruction to specific groups, or library-specific instruction) into a general "instruction" group, and those focusing on programmatic and management issues (i.e., the categories 4.0 through 4.2) into "Program issues." Although the resultant chi-square test was not significant, an examination of the results does show interesting trends. The resulting chart shows that the number of general-essay articles has continued to grow over time, from sixteen in the early 1980s to thirty-five in the late 1990s. The number of 
Table 3. Type of Article for All Articles

2.1 Instruction-Course- or Assignment-Related

\section{Type of Article}

2.2 Instruction-Computer Assisted

2.3a Academically Deficient Students

2.3b International/Multicultural Students

2.3c Undergraduate/Community College Students

2.3d Graduate Students

2.3e High School Students

2.3f Faculty/Staff

$2.3 \mathrm{~g}$ Adult Students

2.3h Other Groups

2.4a Specific Institution Bibliographic Instruction

2.4b Searching Catalogs and Databases (and CD-ROMs)

2.4c Orientation

2.4d Audio-Visual/Multimedia/Microforms

2.4e Workbooks

$2.4 \mathrm{f}$ Internet

3.0 Instruction Preparation/Methodology

4.0 Programmatic/Management Issues

4.1 Examples

4.2 Evaluation of Programs

5.0 Research Methods for Instruction

6.0 Collections/Bibliographies/Literature Reviews

Total

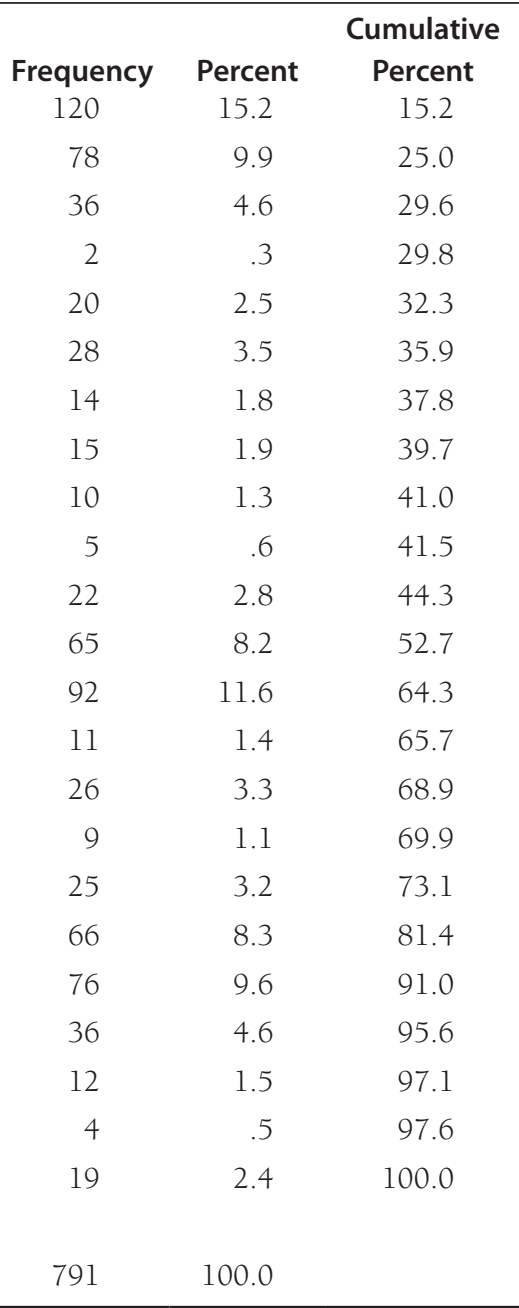

articles on the instruction of special populations peaked in the late 1980s and early 1990s, while articles on programmatic and management issues have grown greatly over the time span studied, e.g., from twelve in the early 1980 s to thirty in the late 1990s.

Out of the 791 total articles, 194 (24.5 percent) can be classed as research-based, meaning that an explicit type of research method was discussed in the article. These articles appeared in forty-five different journals with only five journals publishing more than ten research articles: Research Strategies (thirty-nine), College \& Research Libraries (thirty-six), Reference \& Users Services Quarterly (and RQ) (twenty-four), Journal of Academic Librarianship (seventeen), and Reference Services Review (eleven).

Among those articles classified as researchbased, nine years witnessed the publication of ten or more articles. The greatest number were published in 1992 (eighteen), followed by 1994 (sixteen) and 2002 (fourteen). The five years between 1988 and 1992 saw ten or more research articles per year and accounted for sixty-one articles (31.4 percent). Figure 1 shows the relationship between the total number of articles and the number of research articles per year. As the graph shows, the variability between both numbers is similar in scale. For the total number of articles,

Figure 1. Articles by Year

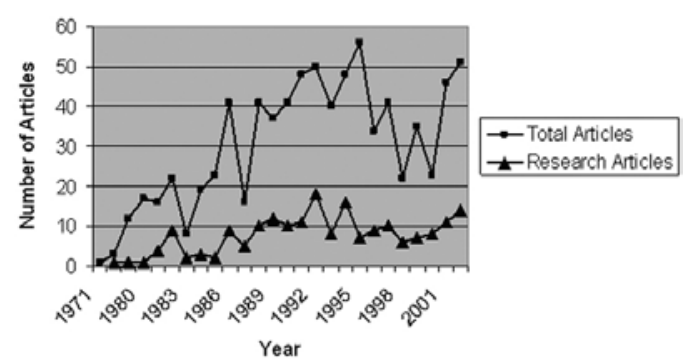


Table 4. Top Journals by Article Type

\begin{tabular}{|c|c|c|}
\hline & $\begin{array}{l}\text { Number of } \\
\text { Article }\end{array}$ & $\begin{array}{l}\text { Percentage of } \\
\text { Category }\end{array}$ \\
\hline \multicolumn{3}{|l|}{ General Essays (120 articles) } \\
\hline Journal of Academic Librarianship & 20 & $16.7 \%$ \\
\hline Research Strategies & 13 & $10.8 \%$ \\
\hline College \& Research Libraries & 11 & $9.2 \%$ \\
\hline Reference Librarian & 9 & $7.5 \%$ \\
\hline \multicolumn{3}{|c|}{ Course- or Assignment-Related Instruction (78 articles) } \\
\hline Research Strategies & 33 & $42.3 \%$ \\
\hline Reference Services Review & 9 & $11.5 \%$ \\
\hline \multicolumn{3}{|c|}{ Instruction of Specific Populations (116 articles) } \\
\hline Research Strategies & 24 & $20.7 \%$ \\
\hline Journal of Academic Librarianship & 15 & $12.9 \%$ \\
\hline Reference \& User Services Quarterly & 11 & $9.5 \%$ \\
\hline \multicolumn{3}{|l|}{ Library-Specific Instruction (228 articles) } \\
\hline Research Strategies & 47 & $20.6 \%$ \\
\hline College \& Research Libraries & 23 & $10.1 \%$ \\
\hline $\begin{array}{l}\text { Reference \& User Services Quarterly } \\
\text { (including RQ) }\end{array}$ & 19 & $8.3 \%$ \\
\hline Reference Services Review & 14 & $6.1 \%$ \\
\hline Journal of Academic Librarianship & 12 & $5.3 \%$ \\
\hline \multicolumn{3}{|c|}{ Instruction Preparation/Methodology (66 articles) } \\
\hline Research Strategies & 14 & $21.2 \%$ \\
\hline College \& Research Libraries & 10 & $15.2 \%$ \\
\hline Reference Services Review & 10 & $15.2 \%$ \\
\hline \multicolumn{3}{|c|}{ Programmatic/Management Issues (124 articles) } \\
\hline Reference Services Review & 19 & $15.3 \%$ \\
\hline Research Strategies & 14 & $11.3 \%$ \\
\hline Reference Librarian & 10 & $8.1 \%$ \\
\hline
\end{tabular}

the mean is 30.4 articles per year (s.d.=15.97), and for the number of research articles, the mean is 7.5 per year (s.d. $=4.82)$.

The most frequent topic of research articles was general bibliographic instruction (22.7 percent) and instruction on searching online catalogs and databases (22.2 percent). Only four other topics were represented by more than ten articles: course- or assignment-related instruction (8.2 percent); instruction of undergraduate and community college students (6.7 percent); instruction preparation/methodology (9.8 percent); and programmatic and management issues ( 7.2 percent).

The last analyses centered on research methods and the use of statistics within those articles classed as research-based. Nine different types of research methods were discovered, as shown in table 6. The total frequency reported was greater than 194 since some of the articles included more than one type of method. The most frequently used research method by far was the survey or questionnaire (62.3 percent). Coming in as a distant

Table 5. Year Group by Article Type for All Articles

\begin{tabular}{|c|c|c|c|c|c|c|c|c|}
\hline Year Group & $\begin{array}{c}\text { General } \\
\text { Essays }\end{array}$ & $\begin{array}{l}\text { Instruction } \\
\text { (Specific } \\
\text { Types and } \\
\text { Groups) }\end{array}$ & $\begin{array}{l}\text { Instruction } \\
\text { Preparation/ } \\
\text { Methodology }\end{array}$ & $\begin{array}{c}\text { Programmatic/ } \\
\text { Management } \\
\text { Issues }\end{array}$ & $\begin{array}{l}\text { Research Methods } \\
\text { for Instruction }\end{array}$ & $\begin{array}{c}\text { Research- } \\
\text { Based }\end{array}$ & $\begin{array}{c}\text { Collections/ } \\
\text { Bibliographies/ } \\
\text { Literature Reviews }\end{array}$ & Total \\
\hline 1970s & 1 & 5 & 3 & 3 & 1 & 2 & 1 & 16 \\
\hline 1985-1989 & 20 & 77 & 9 & 12 & 1 & 38 & 1 & 158 \\
\hline 1990-1994 & 33 & 83 & 12 & 26 & 1 & 63 & 9 & 227 \\
\hline 1995-1999 & 35 & 68 & 12 & 30 & 1 & 39 & 3 & 188 \\
\hline $2000 s$ & 5 & 12 & 2 & 7 & 0 & 10 & 0 & 36 \\
\hline
\end{tabular}


Table 6. Type of Methods Used in Research Articles

\begin{tabular}{|c|c|c|c|}
\hline Survey/Questionnaire & $\begin{array}{c}\text { Frequency } \\
134\end{array}$ & $\begin{array}{c}\text { Percent } \\
62.3\end{array}$ & $\begin{array}{c}\text { Cumulative } \\
\text { Percent } \\
62.3\end{array}$ \\
\hline Experimental Design/Quasi-Experimental Design & 29 & 13.5 & 75.8 \\
\hline Citation/Bibliographic/Transaction Logs/Database Usage & 19 & 8.8 & 87.9 \\
\hline Focus Groups/Interviews & 14 & 6.5 & 96.3 \\
\hline Case Study & 7 & 3.3 & 79.1 \\
\hline Literature Review & 4 & 1.9 & 89.8 \\
\hline Patron Requests (ILL or Reference) & 4 & 1.9 & 100.0 \\
\hline Research Summaries & 2 & .9 & 97.2 \\
\hline Student Journals or Papers & 2 & .9 & 98.1 \\
\hline Total & 215 & 100.0 & \\
\hline
\end{tabular}

second method of research was the use of experimental or quasi-experimental design. In general, these studies employed the use of pre- and posttests to study the effectiveness of academic library instruction. The third most frequently used research type was citation analysis or transaction logs to determine materials and database usage. Several articles also employed the use of interviews or focus groups, often when researching how best to provide instruction to specific groups.

As would be expected, most articles classed as research-based used statistics to bolster the conclusions of the study. An overwhelming majority of the articles used descriptive statistics (86.1 percent), while twenty-seven did not provide any statistical data. In general, most articles provided percentages. Rarely were other descriptive statistics such as the mean or standard deviation given. Often, even the number of cases was missing. Slightly more than a third of the articles (38.1 percent) used inferential statistics. Table 7 gives the types of inferential statistics used. Because many articles employed several different inferential statistical tests, the total is greater than the number of articles using such tests. The most frequently used statistics were chi-square (27.4 percent), t-tests (25.7 percent), analysis of variance or covariance (16.8 percent), and correlation (15.9 percent). Surprisingly, only about a third of the articles that provided inferential statistics discussed the statistical significance of the results. In a few cases, incorrect statistics were used or incorrect statements were made about the statistic being discussed. For example, in one article, the author discussed the use of correlation but in actuality a chi-square test was used.
The discussion of the samples used within the articles, especially for surveys, varied widely. In most instances, the sampling techniques employed were not discussed at all. In addition, the size of the samples varied greatly, with the smallest reported group consisting of an $\mathrm{N}$ of five, and the largest, 4,134 with a mean of 290 (s.d.=564.3). Similarly, the return rate, when reported, varied from a low of 1 percent to a high of 100 percent with a mean of 58 percent (s.d. $=24$ percent), with little discussion provided on the importance of the return rate to the study.

\section{DISCUSSION}

Many of the results of this study could be expected by those familiar with the literature of instruction within academic libraries. The journals that published the greatest number of articles on the topic were those most closely associated with academic librarianship and instruction, such as Research Strategies, Reference Services Review, College \& Research Libraries, the Journal of Academic Librarianship, and Reference \& User Services Quarterly. These results mirror those of Edwards, who found that Research Strategies published the greatest percentage number of articles on instruction, followed by Reference Librarian, College \& Research Libraries, the Journal of Academic Librarianship, Reference \& User Services Quarterly, Catholic Library World, and $R Q .{ }^{23}$ In this study, the journals publishing the most research articles were, in order of the number of articles published: Research Strategies, College \& Research Libraries, Reference \& User Services Quarterly (including RQ), the Journal of Academic Librarianship, and Reference Services Review. 
Table 7. Types of Inferential Statistics

\begin{tabular}{|c|c|c|c|}
\hline Type of Inferential Statistics & Frequency & Percent & $\begin{array}{c}\text { Cumulative } \\
\text { Percent }\end{array}$ \\
\hline Chi-Square & 31 & 27.4 & 27.4 \\
\hline T-Test & 29 & 25.7 & 69.9 \\
\hline $\begin{array}{l}\text { Analysis of Variance (Including Post Hoc Tests) } \\
\text { and Analysis of Covariance }\end{array}$ & 19 & 16.8 & 44.2 \\
\hline Correlation (Pearson, Spearman, Kendall's Tau-B) & 18 & 15.9 & 86.7 \\
\hline Cramer's V & 5 & 4.4 & 95.6 \\
\hline Mann-Whitney-Wilcoxon & 4 & 3.5 & 90.3 \\
\hline Multiple Regression & 3 & 2.7 & 99.1 \\
\hline Kruder-Richardson Estimates & 1 & .9 & 70.8 \\
\hline Kruskal-Wallis Test & 1 & .9 & 100.0 \\
\hline Shapiro-Wilk Test & 1 & .9 & 96.5 \\
\hline Square's Analysis for Return Rate & 1 & .9 & 91.2 \\
\hline Total & 113 & 100.0 & \\
\hline
\end{tabular}

Edwards's results were similar: Research Strategies, College \& Research Libraries, the Journal of Academic Librarianship, $R Q$, and Journal of Education for Library and Information Science.

The number of articles on instruction has varied by year, but there is no discernable trend in the total number of articles published each year, although the late 1980s and the early 1990s did witness greater publication rates than the overall average.

One of the most striking results of this study is the breakdown by article type. More than a quarter (212, 26.3 percent) of the articles represent just two types of articles, specifically general essays and articles on instruction for catalog and database searching. When the data are reduced into broader categories, articles on instruction, whether by type of instruction or for specific populations, become the majority type of article (58 percent).

Although the "Research Agenda for Bibliographic Instruction" has called for greater research activity, these data give evidence that even though research is being regularly conducted, the majority of articles are how-to or essays, instead of being grounded in quantitative or qualitative research methods. Research articles themselves accounted for fewer than one-quarter of the articles included in the study (24.5 percent), and this percentage has held fairly steady over the time span of this study. This number is surprisingly similar to that found by Wallace in his study of the literature of librarianship as a whole and by Feehan et al. in their study of one year's worth of articles. ${ }^{24}$ In addition, the use of sophisticated research methods within those articles that are classed as research is largely absent. Inferential statistics were used in fewer than 40 percent of the articles even though the research methods employed in the studies lent themselves to the use of such statistics. Most articles, when numbers were given, used descriptive statistics alone, again mirroring the findings of Kim and Kim and of Wallace. ${ }^{25}$

\section{CONCLUSIONS}

This research is only one step in trying to understand the status of the literature of instruction, and it builds upon the notable research of many others. It provides a framework for analyzing and discussing the literature and a longitudinal baseline against which changes in the literature can be judged. Additional studies, such as examining in detail the articles classed as research-based, will undoubtedly provide greater insights. Using the "Research Agenda for Library Instruction and Information Literacy: The Updated Version" as an alternate method of grouping articles may also yield interesting results.

The most compelling result of this research is the relative lack of high-quality research in the field of librarianship in general and of libraryrelated instruction in particular. With increasing 
calls for accountability and with the increasing importance that college and university libraries have been placing on library instruction and information literacy, there is a definite need for articles researching the efficacy of the efforts of librarians in these areas. Often the data have already been collected though a variety of assessment tools, both at the micro level of the individual classes being taught and at the macro level with instruments such as LibQual+. Librarians must begin to tap such data, and they must begin to use more sophisticated research methods and statistical techniques to analyze these data. Then, they must disseminate the results through conference papers and through journal articles. Only then can librarianship and library instruction begin to become an evidence-based profession.

\section{References}

1. Research Committee of the ACRL Bibliographic Instruction Section, "Research Agenda for Bibliographic Instruction," CERL News no. 4 (Apr. 1980): 94-95

2. Research and Scholarship Committee of the ACRL Instruction Section, "Research Agenda for Library Instruction and Information Literacy: The Updated Version," CERL News 64, no. 2 (Feb. 2003): 108-13.

3. Hannelore B. Rader, "A Silver Anniversary: 25 Years of Reviewing the Literature Related to User Instruction," Reference Services Review 28, no. 3 (2000): 290-96.

4. Hannelore B. Rader, "Information Literacy 1973 2002: A Selected Literature Review," Library Trends 51, no. 2 (2002): 242-59.

5. Sherri Edwards, "Bibliographic Instruction Research: An Analysis of the Journal Literature from 1977 to 1991," Research Strategies 12, no. 2 (Spring 1994): 68-78.

6. Denise Koufogiannakis, Linda Slater, and Ellen Crumley, "A Content Analysis of Librarianship Research," Journal of Information Science 30, no. 3 (2004): 227-39.

7. Patricia E. Feehan et al., "Library and Information Science Research: An Analysis of the 1984 Journal Literature," Library and Information Science Research 9 , no. 3 (1987): 173-86.

8. Lois Buttlar, "Analyzing the Library Periodical Literature: Content and Authorship," College \& Research Libraries 52 (Jan. 1991): 38-53.

9. Rebecca Watson-Boone, "Academic Librarians as Practitioner-Researchers," Journal of Academic Librarianship 26 (Mar. 2000): 85-93.

10. Soon D. Kim and May T. Kim, "Academic Library Research: A Twenty-Year Perspective," in New Hori- zons for Academic Libraries, eds. Robert D. Stueart and Richard D. Johnson (New York: K. G. Saur, 1979), 375-83.

11. Danny P. Wallace, "The Use of Statistical Methods in Library and Information Science," Journal of the American Society for Information Science 36, no. 6 (1985): 402-10.

12. Evan Farber, "College Libraries and the Teaching/ Learning Process: A Twenty-Five-Year Reflection," Journal of Academic Librarianship 25, no. 3 (May 1999): 171-77.

13. Ibid., 176.

14. Michael Lorenzen, "A Brief History of Library Information in the United States of America," Illinois Libraries 83, no. 2 (Spring 2001): 8-18.

15. Harold B. Shill, "Bibliographic Instruction: Planning for the Electronic Information Environment," College E Research Libraries 48 (Sept. 1987): 433-53.

16. Christopher Bober, Sonia Poulin, and Luigina Vileno, "Evaluating Library Instruction in Academic Libraries: A Critical Review of the Literature, 1980-1993," Reference Librarian no. 51/52 (1995): 53-71.

17. Jean Sheridan, "WAC and Libraries: A Look at the Future," Journal of Academic Librarianship 18, no. 3 (May 1992): 90-94.

18. Kristin Trefts and Sarah Blakeslee, "Did You Hear the One About the Boolean Operators? Incorporating Comedy into Library Instruction," Reference Services Review 28 (2000): 369-77.

19. Ella G. Copeland, "Back to the Future in Bibliographic Instruction," Community and Junior College Libraries 7 (1991): 39-44; Melba Jesudason, "Outreach to Student-Athletes through E-Mail Reference Service," Reference Services Review 28, no. 3 (2000): 262-67; Kate Manuel, "Teaching Information Literacy to Generation Y," Journal of Library Administration 36, no. 1-2 (2002): 195-217; Paul R. Pival and Johanna Tunon, "Innovative Methods for Providing Instruction to Distance Students Using Technology," Journal of Library Administration 32, no. 1-2 (2001): 347-60; and Simon R. Rogers, "Research Strategies: Bibliographic Instruction for Undergraduates," Research Strategies 29 (Summer 1980): 69-81.

20. Anna Marie Johnson and Hannelore B. Rader, "Library Instruction and Information Literacy-2001," Reference Services Review 30, no. 4 (2002): 359-89.

21. Mary Ellen Rutledge Elsbernd, et al., "The Best of OPAC Instruction: A Selected Guide for the Beginner," Research Strategies 8 (Winter 1990): 28-36.

22. Edwards, "Bibliographic Instruction Research."

23. Ibid

24. Wallace, "The Use of Statistical Methods in Library and Information Science"; Feehan et al., "Library and Information Science Research."

25. Kim and Kim, "Academic Library Research"; Wallace, "The Use of Statistical Methods in Library and Information Science." 


\section{FEATURE}

\section{APPENDIX}

\section{Coding Scheme}

1.0 General essays (e.g., current developments, opinions, trends, philosophy)

2.1 Instruction-Course- or Assignment-Related

2.2 Instruction-Computer Assisted

2.3 Instruction-Special Populations:

2.3a Academically deficient students

2.3b International/multicultural students

2.3c Undergraduate/community college students

2.3d Graduate students

2.3e High school students

$2.3 \mathrm{f}$ Faculty/staff

2.3g Adult students

2.3h Other

2.4 Library-specific instruction

2.4a Bibliographic instruction, in general

2.4b Searching catalog and databases (includes CD-ROM)

2.4c Orientation

2.4d Audio-visual/multimedia/microforms

2.4e Workbooks

2.4f Internet

3.0 Instruction preparation/methodology (i.e., how to teach, learning styles)

4.0 Programmatic/management issues

4.1 Examples

4.2 Evaluation of Programs

5.0 Research methods for instruction (i.e., how to do research on instructionnot instructing students, etc., in library research)

6.0 Collections/bibliographies/literature reviews

\section{INDEX TO ADVERTISERS}

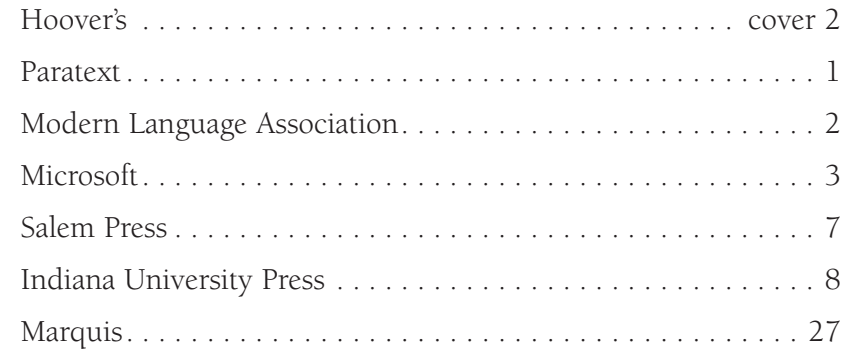

ABC-Clio. . . . . . . . . . . . . . . . . . 44

Bernan. ..........................60 60

Haworth Press. . . . . . . . . . . . . . . . . 76

Cambridge University Press. . . . . . . . . . . . . . . . . 103

Sage. ............................. cover 3

Omnigraphics ......................... cover 4

Plunkett Research Ltd. . . . . . . . . . . . . . . . . insert 